\title{
Nerve Growth Factor (NGF)-Mediated Protection of Neural Crest Cells from Antimitotic Agent-Induced Apoptosis: The Role of the Low-Affinity NGF Receptor
}

\author{
Megan H. Cortazzo, Edmund S. Kassis, Kari A. Sproul, and Nina Felice Schor \\ Departments of Pediatrics, Neurology, and Pharmacology, University of Pittsburgh, Pittsburgh, Pennsylvania 15213
}

Prevention by nerve growth factor (NGF) of apoptotic death in neural cells has been variously ascribed to binding of NGF to its low-affinity ( $p 75)$ or high-affinity (trkA) receptor or to a cooperative interaction between the two. In a series of studies using, in turn, neuroblastoma cell lines that express only $\mathrm{p} 75$, mutant NGF species that bind selectively to either p75 or trkA, and a polyclonal antibody that binds to the NGF-binding domain of p75, we demonstrate that NGF binding to p75 is both necessary and sufficient for the abrogation of apoptosis in neuroblastoma cells treated with antimitotic agents.

Key words: neuroblastoma; NGF; NGF receptors; $p 75$; trkA; apoptosis
The response of cultured cells of neural lineage to such insults as serum deprivation can be modulated by nerve growth factor (NGF) (Ibanez et al., 1992; Rabizadeh et al,, 1993). It is not entirely clear what role each of the two known NGF receptors [low-affinity (p75) and high-affinity (trkA)] play in this modulatory activity. It has been suggested that $\mathrm{p} 75$ expression is required for the induction of apoptosis in response to these insults. Furthermore, the binding of NGF to transfection-derived $\mathrm{p} 75$ appears to be protective against this apoptosis induction in immortalized cerebellar neurons in culture (Rabizadeh et al., 1993). However, other studies have suggested that trkA binding of NGF is sufficient for ensuring the survival of sympathetic neurons in culture (Ibanez et al., 1992). Finally, more recent studies indicate that trkA and p75 exhibit a cooperative relationship, and that both participate in the mediation of the protective and other effects of NGF on neurons (Barker and Shooter, 1994; Huber and Chao, 1995; Wolf et al., 1995).

We have demonstrated previously that cultured neural-type neural crest tumor cells uniformly undergo apoptosis in response to mitotic arrest induced by a variety of agents with different proximate mechanisms of action (Hartsell et al., 1995, 1996). In all cases, treated cells round up, detach from the culture surface, and demonstrate Hoechst dye- and electron microscopy-visible condensation, fragmentation, and margination of nuclear material accompanied by the formation of oligonucleosomal-sized DNA fragments (gel electrophoresis and alkaline elution). Furthermore, the endonuclease inhibitor aurintricarboxylic acid abrogates the ultimate death of neural crest cells treated with antimitotic agents.

\footnotetext{
Received Feb. 20, 1996; revised March 28, 1996; accepted March 28, 1996.

This study was supported by National Institutes of Health Grant 1F33-C 167421 (N.F.S.) and American Cancer Society Grant DPH-128 (N.F.S.), and by research fellowships from the University of Pittsburgh School of Medicine (E.S.K., M.H.C.) and the National Institute of Mental Health (University of Pittsburgh Undergraduate Research Program; M.H.C.). The authors thank Drs. John W. Winslow and Moses V. Chao for helpful discussions and for mutant NGF species and antibody 9651 , respectively, used in these studies. We also acknowledge the expert technical assistance of Karen D. Nylander.

Correspondence should be addressed to Dr. Nina Felice Schor, Division of Child Neurology, Children's Hospital of Pittsburgh, 3705 Fifth Avenue, Pittsburgh, PA 15213.

Copyright (C) 1996 Society for Neuroscience $\quad 0270-6474 / 96 / 163895-05 \$ 05.00 / 0$
}

We also have shown that NGF is protective against antimitotic agent-induced apoptotic death in some of these cell lines (Falcione et al., 1993; Cortazzo et al., 1995). This paper addresses the role of $\mathrm{p} 75$ in mediating the protective activity of NGF in neuroblastoma cells exposed to antimitotic agents.

The use of site-directed mutagenesis to produce NGF species modified at specific amino acid residues has facilitated identification of those residues critical for binding of NGF to either trkA or $\mathrm{p} 75$. These studies indicate that residues $32-35$ are critical for $\mathrm{p} 75$, and not trkA, binding (Ibanez et al., 1992), whereas residues 1-7 are important for trkA, and not p75, binding (Shih et al., 1994) of NGF. Furthermore, the recognition of the distinct trkA- and p75-binding regions of NGF has permitted development of antibodies that selectively block binding of NGF to p75 (Huber and Chao, 1995). Using these reagents and taking advantage of our previous finding that loss of cell adherence is a marker for apoptosis in this system (Hartsell et al., 1995), we have tested the necessity for and sufficiency of p75 binding of NGF for protection of neuroblastoma cells from antimitotic agent-induced apoptosis.

\section{MATERIALS AND METHODS}

Chemicals. The antimitotic agent neocarzinostatin (NCS) was obtained from Kayaku Pharmaceuticals (Tokyo, Japan). NCS was stored in powder form at $-20^{\circ} \mathrm{C}$; a $47 \mu \mathrm{M}(0.5 \mathrm{mg} / \mathrm{ml})$ working stock solution in $0.015 \mathrm{M}$ sodium acetate buffer, $\mathrm{pH} 5.0$, was stored in the dark at $4^{\circ} \mathrm{C}$ for up to 2 weeks and diluted with medium immediately before each cxpcriment. NGF was obtained from Bochringer Mannheim (Indianapolis, IN) and stored at $-20^{\circ} \mathrm{C}$ as a stock solution $(100 \mu \mathrm{g} / \mathrm{ml})$ in minimal essential medium- $\alpha$ made $10 \%$ in fetal bovine serum. A polyclonal antiserum (Ab 9651) directed against the extracellular domain of the p75 NGF receptor was obtained from Dr. Moses V. Chao (Comell University Medical College, New York, NY) and used for all experiments in a 1:1000 dilution. This antibody blocks NGF binding to p75 (Huber and Chao, 1995). All mutant NGF species were obtained from Dr. John W. Winslow (Genentech, South San Francisco, CA). Mutant 6 (S1Y, S2A, S3E, P5K, I6S, F7S) is 100 -fold p 75 -selective at $25-37^{\circ} \mathrm{C}$ (Shih et al., 1995). Mutants 21 (K32A, K34A, E35A) and 24 (R115A, K116A, R119A) are 100-fold trkA-selective (Ibanez et al., 1992) (J. W. Winslow, Genentech, personal communication).

Cell lines and culture. Two human neuroblastoma cell lines were used for these studies. SH-SY5Y cells were obtained from Dr. June L. Biedler (Memorial-Sloan Kettering Cancer Center, New York, NY) and maintained as adherent monolayers on plastic tissue culture flasks $\left(37^{\circ} \mathrm{C}, 5 \%\right.$ $\mathrm{CO}_{2}$ ) with a $1: 1$ mixture of minimal essential medium- $\alpha$ and Ham's F-12 
A

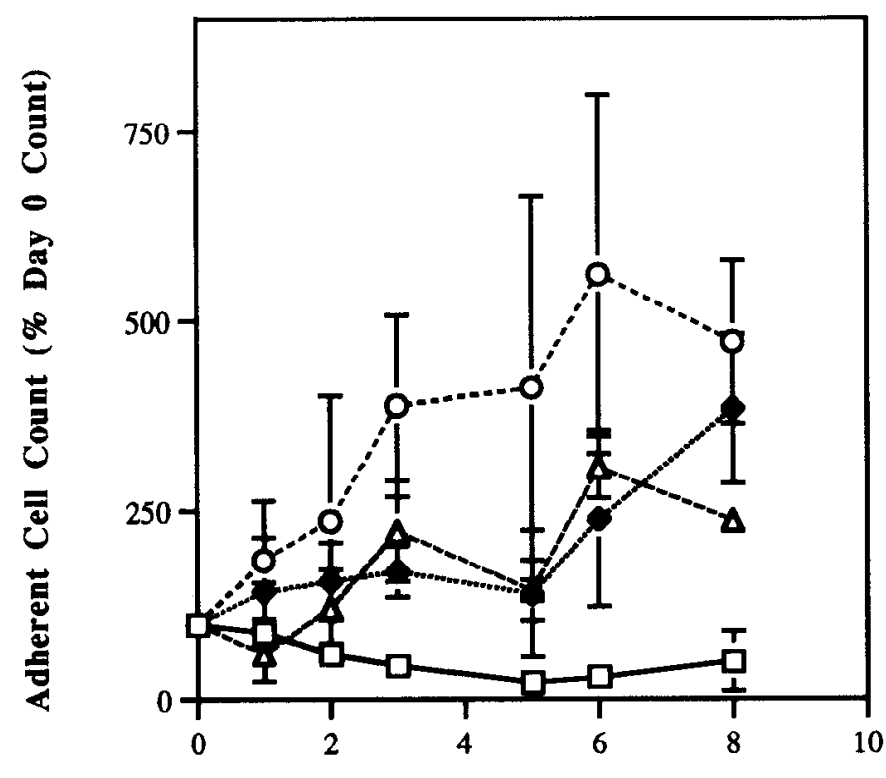

Day
B

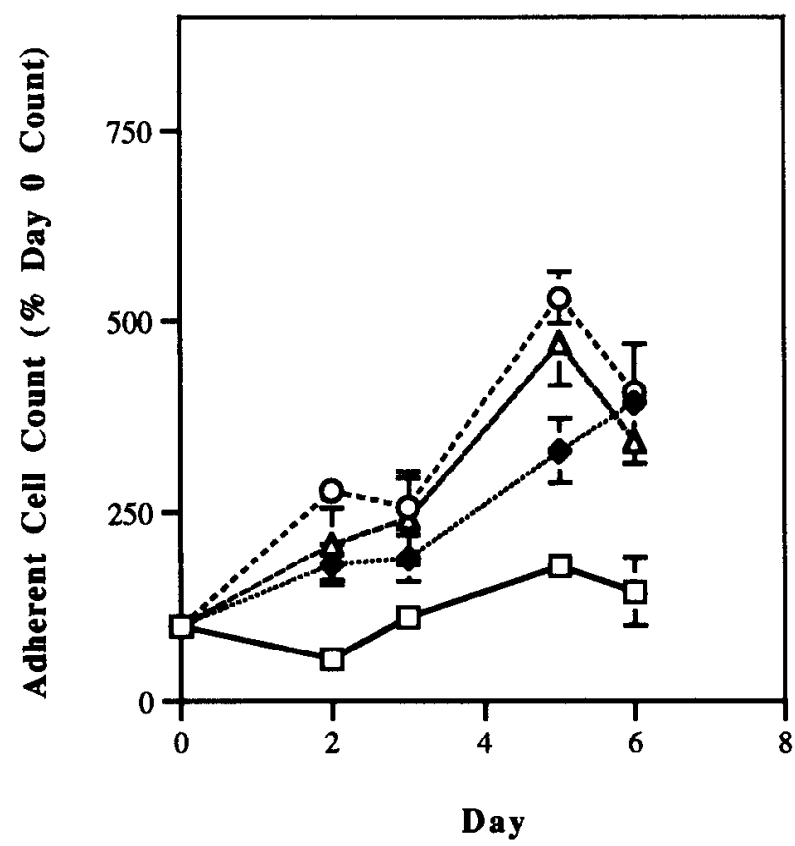

Figure 1. Effects of NGF (42 nM) on antimitotic agent-induced human neuroblastoma cell death. $A$, SH-SY5Y cells were pretreated with NGF for 24 $\mathrm{hr}$, then exposed for $1 \mathrm{hr}$ to $3.2 \mathrm{nM}$ NCS in the presence of NGF. $B$, NGP cells were pretreated similarly with NGF, then exposed for $1 \mathrm{hr}$ to $2.4 \mathrm{~nm}$ NCS in the presence of NGF. In both cases, NGF was maintained in the culture medium for the duration of the experiment. The relationship between cell adherence and apoptosis and the methods for determining adherent cell counts have been described in detail previously (Falcione et al., 1993; Hartsell et al., 1995). In this and the following figures, error bars represent the SEM of three determinations within a single representative experiment and, where not apparent, are smaller than the size of the symbol. All experiments were performed twice, and each repetition gave comparable results to those shown. $\square$, NCS alone; $\bullet$ NCS + NGF; O, NGF alonc; $\triangle$, control.

nutrient mixture supplemented with $10 \%$ fetal bovine serum. NGP cells were the kind gift of Dr. Garrett Brodeur (Children's Hospital of Philadelphia, Philadelphia, PA) and were maintained as adherent monolayers with minimal essential medium- $\alpha$ made $10 \%$ in fetal bovine serum. For all experiments, cells were transferred from stock flasks to 6-well plates and allowed to incubate overnight before initiating experimental manipulations.

Effects of native and mutant NGFs on the NCS-induced decrement in adherent cell number. The association of detachment from the tissue culture surface with the occurrence of apoptosis has been noted for many different cell types (Couldwell et al., 1994; Martin and Green, 1994; Weller et al. 1994; Hartsell et al., 1995), although the mechanism of this detachment is not known (Martin and Green, 1994). The effects of NGF on the decrease in adherent cell number induced by NCS were determined, as we have described previously (Falcione et al., 1993). Briefly, sister cultures were exposed continuously to NGF or control medium from $24 \mathrm{hr}$ before NCS treatment through the termination of the experiment. In studies involving $\mathrm{Ab} 9651$, the antibody was added to the culture (1:1000 dilution) $1 \mathrm{hr}$ before the addition of NGF and maintained in the medium for the duration of the expcriment. After $24 \mathrm{hr}$ of NGF exposure, cells were treated for $1 \mathrm{hr}$ at $37^{\circ} \mathrm{C}$ with NCS. The adherent cell number was determined for each culture immediately after treatment with NCS and each day thereafter for the duration of the experiment, as we have described previously (Falcione et al., 1993; Hartsell et al., 1995, 1996).

\section{RESULTS}

\section{Sufficiency of binding to p75 for the protective effects} of NGF on NCS-treated neuroblastoma cells

We have demonstrated previously that SH-SY5Y human neuroblastoma cells undergo apoptosis when treated with antimitotic agents, and that in cultures of these cells, loss of adherence of cells to the tissue culture surface inevitably presages the occurrence of apoptosis defined by Hoechst dye staining, electron microscopy, DNA electrophoresis, alkaline elution, and response to endonu- clease inhibition (Hartsell et al., 1995). SH-SY5Y cells express both $\mathrm{p} 75\left(1.3 \times 10^{5} / \mathrm{cell}\right)$ and trkA $\left(2.6 \times 10^{3} / \mathrm{cell}\right)$, and bind NGF at both of these receptors (Azar et al., 1991). They are protected completely by NGF from the NCS-induced decrement in adherent cell number (Fig. 1A).

To determine whether NGF binding to $\mathrm{p} 75$ alone is sufficient to induce resistance of neuroblastoma cells to antimitotic agent-induced apoptosis, the effects of NGF on NGP human neuroblastoma cell adherence were determined. NGP cells express p $75\left(2.7 \times 10^{4}\right.$ receptors/cell), but not trkA (Azar et al., 1991). NGF (40 nM) completely protected NGP cells from the effects of NCS (Fig. 1B).

Because the SH-SY5Y and NGP lines undoubtedly differ from one another in characteristics other than NGF receptor expression, sufficiency of p75 binding also was tested by treating SHSY5Y cells continuously with a mutant NGF that binds to p75 with a 100 -fold greater affinity than to trkA. Figure $2 A$ demonstrates that this p75-selective NGF mutant 6 (Shih et al., 1995) completely protects SH-SY5Y cells from the effects of NCS. Mutant 6 has no effect on the growth or survival of native SHSY5Y cultures.

\section{Insufficiency of binding to trkA for the protective effects of NGF}

To determine the role of NGF binding to trkA in the protection of neuroblastoma cells from antimitotic-induced apoptosis, $\mathrm{SH}-$ SY5Y cells were exposed continuously to trkA-specific NGF mutants 21 and 24 (Shih et al., 1995). These mutants are 100-fold selective for trkA relative to $\mathrm{p} 75$. Neither of these compounds protected SH-SY5Y cells from the NCS-induced decrement in 
A

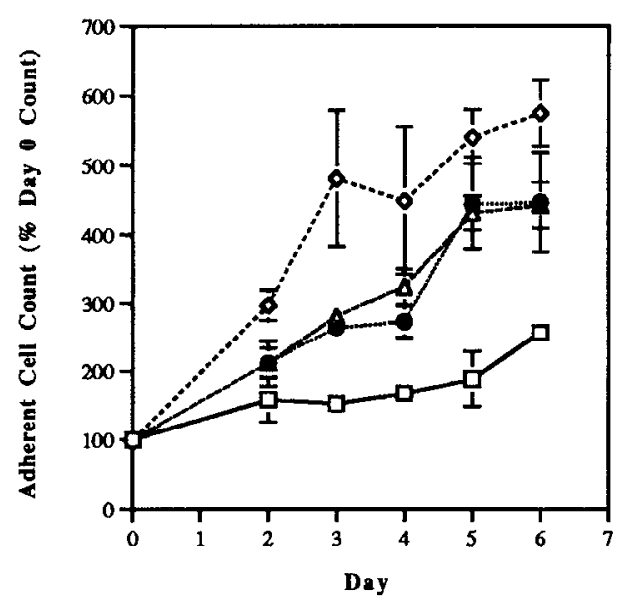

B

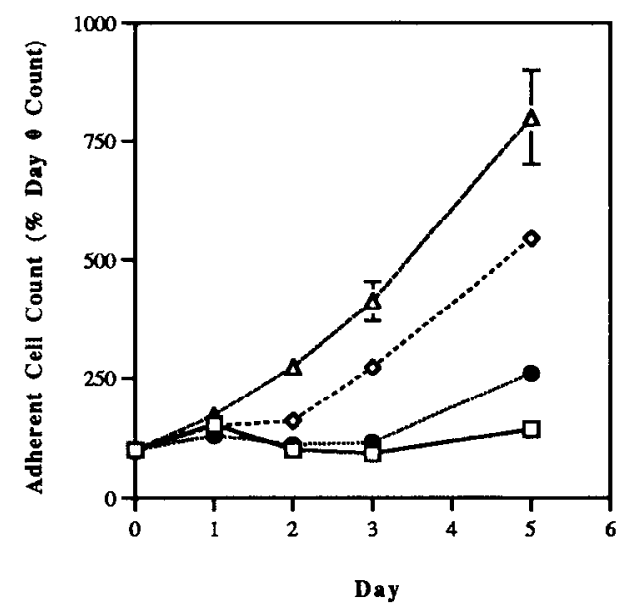

C

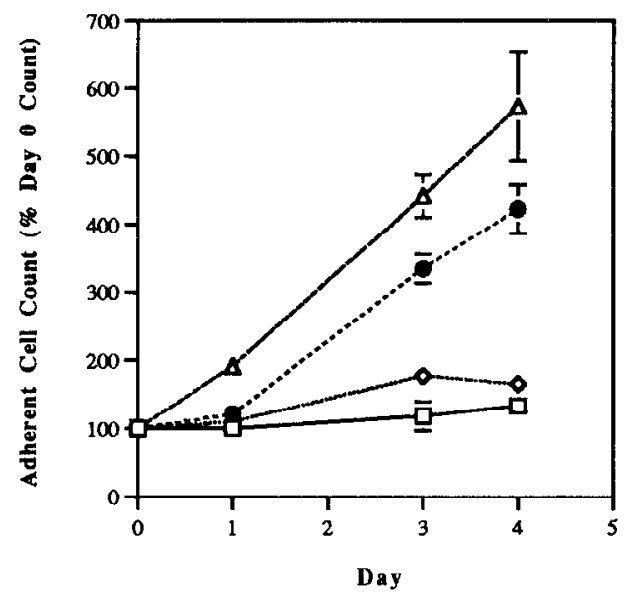

Figure 2. Effects of p75- and trkA-selective mutant NGF species (4.2 nM) on antimitotic agent-induced SH-SY5Y cell death. Mutant NGF species produced by site-directed mutagenesis were obtained from John W. Winslow (Genentech) and have been fully characterized as described previously (Shih et al., 1994). Mutant $6(A)$ is p75-selective; mutants $21(B)$ and $24(C)$ are trkA-selective. In all cases, the duration of NCS (1.6 nM) treatment was $1 \mathrm{hr}$, and mutant NGF exposure began $24 \mathrm{hr}$ before NCS treatment and continued throughout the duration of the experiment. $\square$, NCS alone; $\bullet$ NCS + mutant NGF; $\diamond$, control; $\triangle$, mutant NGF alone.

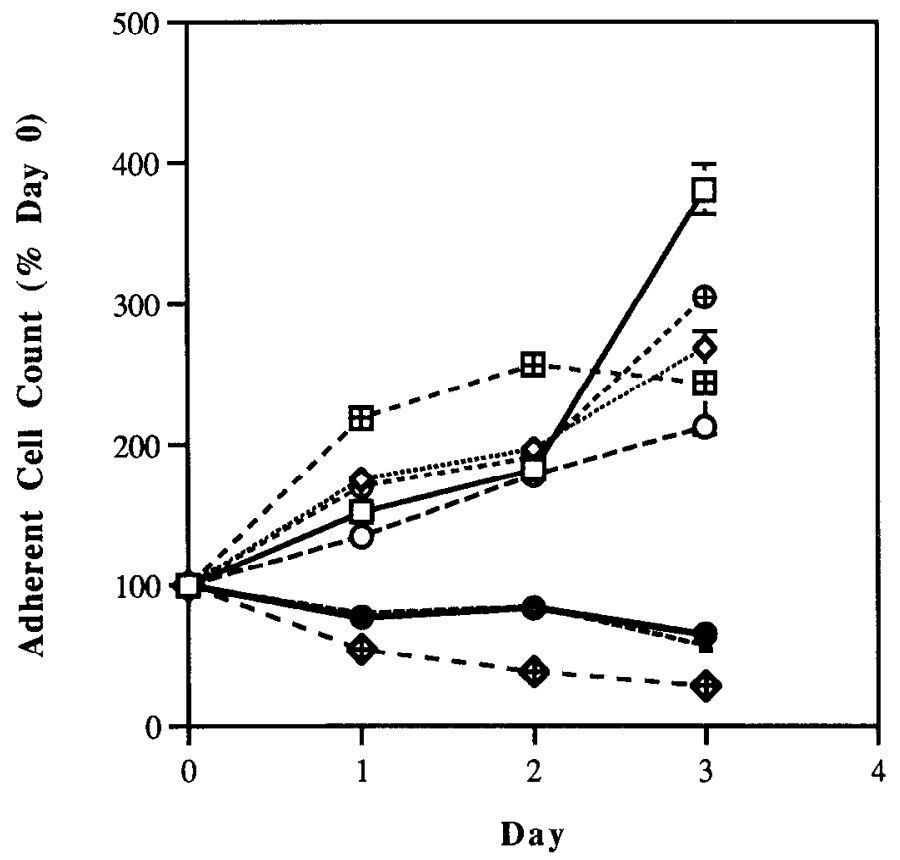

Figure 3. Effects of antibody $9651(1: 10000)$ on the protective effects of NGF (42 nM) in antimitotic agent-treated SH-SY5Y cells. Antibody 9651 was obtained from Moses V. Chao (Cornell University Medical College). This antibody specifically blocks NGF binding to the extracellular domain of p75 (Huber and Chao, 1995). Cells were incubated with antibody for 1 hr before the addition of NGF, and both antibody and NGF were maintained in the medium throughout the duration of the experiment. NCS (1.6 nM) treatment was $1 \mathrm{hr}$ in duration, beginning $24 \mathrm{hr}$ after the addition of NGF to the medium. $\square$, Control; $\diamond, N G F$ alone; $\oplus, N G F+$ antibody 9651; $\mathbf{\Delta}, \mathrm{NCS}$ alone; $\boxplus, \mathrm{NGF}+\mathrm{NCS} ; \bullet, \mathrm{NGF}+$ antibody $9651+\mathrm{NCS}$; $\circ$, antibody 9651 alone; $\oplus$, antibody $9651+$ NCS.

adherent cell number (Fig. $2 B, C$ ). Interestingly, both mutants 21 and 24 alone enhanced the growth rate of SH-SY5Y cultures.

\section{Necessity for p75 binding for the protective effects of NGF}

In an effort to establish the requirement for $\mathrm{p} 75$ binding for the protective effects of NGF in this systcm, SH-SY5Y cells were treated with NGF and NCS in the presence or absence of $A b$ 9651. This antibody recognizes the extracellular domain of $\mathrm{p} 75$ and blocks binding of NGF to this receptor (Huber and Chao, 1995). As is demonstrated in Figure 3, Ab 9651 abrogates the protective activity of NGF in neuroblastoma cells treated with NCS, indicating the necessity for p75 binding in this regard. The antibody itself had no effect on adherent cell number in either native cultures or cultures treated with NCS.

\section{DISCUSSION}

Apoptosis, the process by which cells orchestrate their own demise in response to intra- or extracellular events, plays a major role in normal, pathological, and iatrogenic processes in the nervous system (Cotter et al., 1990; Raff, 1992; Wyllie, 1992). In non-nervous system models, several endogenous factors have been shown to protect tumor and/or normal cells from apoptotic death (Brach et al., 1992; Tilly et al., 1992; Harrington et al., 1994; Ishizaki et al., 1994). These agents have been referred to collectively as "survival factors" (Collins et al., 1994). For both normal and neoplastic neural crest-derived cells, NGF acts as a survival factor that protects against apoptosis initiated by a variety of exogenous conditions (Ibanez et al., 1992; Rabizadeh et al., 1993). 
We have reported previously on antimitotic agent-induced apoptosis in neuroblastoma cells and the protection by NGF of these cells from apoptosis induced by such agents (Falcione et al., 1993; Cortazzo et al., 1995; Hartsell et al., 1995). This antimitotic agent-induced apoptosis resembles apoptosis induced in neural cells by other stimuli; it is prevented by incubation with NGF, protein synthesis inhibitors, or endonuclease inhibitors, and is accompanied by all of the changes in morphology and nuclear chromatin size and configuration that have become the hallmarks of apoptosis (Bredesen, 1995; Hartsell et al., 1995).

Two cell surface receptors have been identified for NGF. TrkA binds NGF with high affinity, whereas $\mathrm{p} 75$ binds this peptide with low affinity (Barbacid, 1993). From the functional standpoint, trkA is the starting point for a protein kinase signal transduction pathway that clearly mediates the differentiative function of NGF. Many of the intermediate steps in the pathway from trkA binding of NGF to the induction of neurite outgrowth have been identified (Cordon-Cardo et al., 1991; Kaplan et al., 1991, Kremer et al., 1991, Ohmichi et al., 1991; Saltiel and Ohmichi, 1993). The functional role of p75 is, by contrast, much less well characterized. Studies in some systems suggest that $\mathrm{p} 75$ functions in concert with trkA to increase the binding affinity of trkA for NGF (Hempstead et al., 1991). More recently, an independent role has been suggested for p75 in the induction of apoptosis in neural cells. Furthermore, the binding of NGF to p75 appears to abrogate this apoptosis-inducing activity (Rabizadeh et al., 1993).

The amino acids that contribute to binding of NGF to each of its receptors have been determined. Each of these receptors has a unique binding site on the $\mathrm{NGF}$ molecule, and the binding of NGF to each receptor can be modulated independently by sitedirected mutagenesis (Ibancz et al., 1992; Shih et al., 1994). In this manner, specific mutant NGF species have been produced that exhihit selectivity of binding to trkA or to p75 (Ibanez et al., 1992; Shih et al., 1994). Using these mutant NGFs and an antibody that specifically blocks NGF binding to p75 (Huber and Chao, 1995), the present studies demonstrate that binding of NGF to p75 is both necessary and sufficient for the protective effects of NGF in neuroblastoma cells treated with antimitotic agents.

Studies of other cultured neuronal systems indicate some variability from system to system in the sufficiency of p75 and the requirement for trkA binding of NGF in this regard. In immortalized cerebellar neurons deprived of serum, transfection with a p75 expression construct is required and sufficient for NGF to abrogate the incidence of apoptosis (Rabizadeh et al., 1993). In contrast, early studies in PC12 pheochromocytoma cells and cultured sympathetic neurons suggested the sufficiency of binding of NGF to trkA for ensuring the survival of these cells (Ibanez et al., 1992). More recent studies in PC12 cells indicate a cooperative relationship between p75-bound NGF and trkA (Canossa et al., 1995). Specifically, at least one of the activities of the p75-NGF complex appears to be enhancement of the NGF binding and autophosphorylation activities of trkA (Barker and Shooter, 1994; Verdi et al., 1994). There is some evidence to suggest that variations from cell line to cell line in the degree of couperalivity between $\mathrm{p} 75$ and trkA are related to the relative abundance of these two receptors on the cell. Interaction between the two receptors appears to require a 3 - to 10 -fold excess of p75 (Verdi et al., 1994; Greene and Kaplan, 1995). This is in contrast to the 100-fold excess on SH-SY5Y cells (Azar et al., 1991).

Our finding of a proliferative response of SH-SY5Y cells to trkA-selective mutant NGFs is in contrast to the brief proliferative, then differentiative, response of normal neural crest cells to
NGF. Defects in the trkA signal transduction pathway and a lack of differentiative response to NGF have been found in several neuroblastoma cell lines, including the SK-N-SH line from which SH-SY5Y cells are derived (Azar et al., 1991). It is, perhaps, these defects that result in the persistence of proliferation seen with trkA binding of NGF.

Differences in the cellular mediators of the protective effects of NGF are of more than mechanistic interest. For example, the use of selective activators of one or the other NGF receptor may have relevance for targeted therapy in the rapidly expanding list of neurodegenerative conditions that involve apoptosis in their pathogeneses (Cotman and Anderson, 1995). Furthermore, binding of NGF to p75 may be of etiological importance in the well-documented clinical phenomenon of neuroblastoma resistance to chemotherapy (Blatt et al., 1995). If differences in the mediators of the protective activity of NGF exist among cell types or among apoptosis-inducing insults, it will be critical to define the nature of such differences before designing therapeutic approaches to particular conditions affecting particular nervous system cells. Previous studies have defined a relationship between trk protein expression and clinical prognosis in neuroblastoma tumor specimens (Nakagawara et al., 1993; Nakagawara et al., 1994; Matsumoto et al., 1995; Yamashiro et al., 1996). Although the expression of trkA, trkC, and a truncated transcript for trkB correlates with a more favorable prognosis, the expression of a full-length transcript for trkB is associated with more aggressive tumors. This relationship is thought to reflect differences among tumors in the degree of cellular maturation. These differences, in turn, influence malignant potential of the tumors (Lucarelli et al., 1995).

Although the relationship between p75 expression and clinical prognosis has not been determined, it has been suggested that the spontaneous regression of neuroblastomas of clinical stage IVS (Evans et al., 1991) is related to the occurrence of apoptosis in these tumors (Prichard and Hickman, 1994). Additional studies are required to determine the roles of apoptosis and p75 expression in the clinical and pathological regression of neuroblastoma.

\section{REFERENCES}

Azar C, Scavarda NJ, Reynolds CP, Brodeur GM (1991) Multiple defects of the nerve growth factor receptor in human neuroblastomas. Prog Clin Biol Res 366:219-226.

Barbacid M (1993) Nerve growth factor: a tale of two receptors. Oncogene 8:2033-2042.

Barker PA, Shooter EM (1994) Disruption of NGF binding to the low affinity neurotrophin receptor $\mathrm{p} 75^{\mathrm{INTR}}$ reduces NGF binding to trkA on PC12 cells. Neuron 13:203 215.

Blatt J, Gula MJ, Orlando SJ, Finn LS, Misra DN, Dickman PS (1995) Indolent course of advanced neuroblastoma in children older than 6 years at diagnosis. Cancer 76:890-894.

Brach MA, deVos S, Gruss HJ, Herrmann F (1992) Prolongation of survival of human polymorphonuclear neutrophils by granulocytemacrophage colony-stimulating factor is caused by inhibition of programmed cell death. Blood 80:2920-2924.

Bredesen D (1995) Neural apoptosis. Ann Neurol 38:839-851.

Canossa M, Twiss JL, Verity AN, Shooter EM (1995) Low affinity NGF receptor $\left(\mathrm{p} 75^{\mathrm{NGFR}}\right)$-associated protein kinase activity. Soc Neurosci Abstr 21:808.

Collins MK, Perkins GR, Rodriguez-Tarduchy G, Nieto MA, Lopez-Rivas A (1994) Growth factors as survival factors: regulation of apoptosis. Bioessays 16:133-138.

Cordon-Cardo C, Tapley P, Jung S, Nanduri V, O'Rourke E, Lamballe F, Kovary K, Klein R, Jones KR, Reichardt LF, Barbacid M (1991) The trk tyrosine protein kinase mediates the mitogenic properties of nerve growth factor and neurotrophin-3. Cell 66:173-183. 
Corta77o M, Nylander KD, Schor NF (1995) NGF-mediated resistance of neuroblastoma to chemotherapeutic-induced apoptosis: the role of the low-affinity receptor. Ann Neurol 38:517.

Cotman $\mathrm{CW}$, Anderson $\Lambda \mathrm{J}(1995) \Lambda$ potential role for apoptosis in neurodegeneration and Alzheimer's disease. Mol Neurobiol 10:19-45.

Cotter TG, Lennon SV, Glynn JG, Martin SJ (1990) Cell death via apoptosis and its relationship to growth, development, and differentiation of both tumour and normal cells. Anticancer Res 10:1153-1160.

Couldwell WT, Hinton DR, He S, Chen TC, Sebat I, Weiss MH, Law RE (1994) Protein kinase C inhibitors induce apoptosis in human malignant glioma cell lines. FEBS Lett 345:43-46.

Evans AE, D'Angio GJ, Randolph J (1991) A proposed staging for children with neuroblastoma: Children's Cancer Study Group A. Cancer 27:374-378.

Falcione M, Milligan KD, Schwartz MC, Schor NF (1993) Prevention of neocarzinostatin-induced cell death and morphologic change in SK$\mathrm{N}$-SH human neuroblastoma cells by continuous exposure to nerve growth factor. Biochem Pharmacol 46:731-738.

Greene LA, Kaplan DR (1995) Early events in neurotrophin signalling via Trk and p75 receptors. Curr Opin Neurobiol 5:579-587.

Harrington EA, Bennett MR, Fanidi A, Evan GI (1994) c-Myc-induced apoptosis in fibroblasts is inhibited by specific cytokines. EMBO J 13:3286-3295.

Hartsell. TL, Yalowich JC, Ritke M, Martinez AJ, Schor NF (1995) Induction of apoptosis in murine and human neuroblastoma cell lincs by the enediyne natural product neocarzinostatin. J Pharmacol Exp Ther 275:479-485.

Hartsell TL, Hinman LM, Hamann PR, Schor NF (1996) Determinants of the response of neuroblastoma cells to DNA damage: the roles of pretreatment cell morphology and chemical nature of the damage. J Pharmacol Exp Ther, in press.

IIempstead BL, Martin-Zanca D, Kaplan DR, Parada LF, Chao MV (1991) High-affinity NGF binding requires co-expression of the trk protooncogene and the low affinity NGF receptor. Nature 350:678-683.

Huber LJ, Chao MV (1995) A potential interaction of p75 and trkA NGF receptors revealed by affinity crosslinking and immunoprecipitation. J Neurosci Res 40:557-563.

Ibanez CF, Ebendal T, Barbany G, Murray-Rust J, Blundell TL, Persson H (1992) Disruption of the low affinity receptor-binding site in NGF allows neuronal survival and differentiation by binding to the trk gene product. Cell 69:329-341.

Ishizaki Y, Burne JF, Raff MC (1994) Autocrine signals enable chondrocytes to survive in culture. J Cell Biol 126:1069-1077.

Kaplan DR, Hempstead BL, Martin-Zanca D, Chao MV, Parada LF (1991) The trk proto-oncogene product: a signal transducing receptor for nerve growth factor. Science 252:554-558.

Kremer NE, D'Arcangelo GD, Thomas SM, DeMarco M, Brugge JS (1991) Signal transduction by nerve growth factor and fibroblast growth factor in $\mathrm{PCl} 2$ cells requires a sequence of src and ras actions. $\mathrm{J}$ Cell Biol 115:809-819.

Lucarelli E, Kaplan DR, Thiele CJ (1995) Selective regulation of TrkA and TrkB receptors by retinoic acid and interferon- $\gamma$ in human neuroblastoma cell lines. J Biol Chem 270:24725-24731.
Martin SJ, Green DR (1994) Apoptosis as a goal of cancer therapy. Curr Opin Oncol 6:616-621.

Matsumoto K, Wada RK, Yamashiro JM, Kaplan DR, Thiele CJ (1995) Expression of braill-derived neurotrophic factor and p145 TrkB affects survival, differentiation, and invasiveness of human neuroblastoma cells. Cancer Res 55:1798-1806.

Nakagawara A, Arima-Nakagawara M, Scavarda NJ, Azar CG, Cantor AB, Brodeur GM (1993) Association between high levels of expression of the TRK gene and favorahle outcome in human neuroblastoma. $\mathrm{N}$ Engl J Med 328:847-854.

Nakagawara A, Azar CG, Scavarda NJ, Brodeur GM (1994) Expression and function of TrkB and BDNF in human neuroblastomas. Mol Cell Biol 14:759-767.

Ohmichi M, Decker SJ, Pang L, Saltiel AR (1991) Nerve growth factor binds to the $140 \mathrm{kd}$ trk proto-oncogene product and stimulates its association with the src homology domain of phospholipase C- $\gamma 1$. Biochem Biophys Res Commun 179:217-223.

Prichard J, Hickman JA (1994) Why does stage 4S neuroblastoma regress spontaneously? Lancet 344:869-870.

Rabizadch S, Oh J, Zhong L-t Yang J, Bitler CM, Butcher LL, Bredesen DE (1993) Induction of apoptosis by the low-affinity NGF receptor. Science 261:345-348.

Ratf MC (1992) Social controls on cell survival and cell death. Nature 356:397-400.

Saltiel AR, Ohmichi M (1993) Pleiotropic signaling from receptor tyrosine kinases. Curr Opin Neurobiol 3:352-359.

Shih A, Laramec GR, Schmelzer CH, Burton LE, Winslow JW (1994) Mutagenesis identifies amino-terminal residucs of ncrve growth factor necessary for trk receptor binding and biological activity. J Biol Chem 269:27679-27686.

Tilly JL, Billig H, Kowalski KI, Hsueh AJ (1992) Epidermal growth factor and basic fibroblast growth factor suppress the spontaneous onset of apoptosis in cultured rat ovarian granulosa cells and follicles by a tyrosine kinase-dependent mechanism. Mol Endocrinol 6:1942-1950.

Verdi JM, Birren SJ, Ibanez CF, Persson H, Kaplan DR, Benedetti M, Chao MV, Anderson DJ (1994) p $75^{\text {LNGFR }}$ regulates Trk signal transduction and NGF-induced neuronal differentiation in MAH cells. Neuron 12:733-745.

Weller M, Frei K, Groscurth P, Krammer PH, Yonekawa Y, Fontana A (1994) Anti-Fas/APO-1 antibody-mediated apoptosis of cultured human glioma cells. Induction and modulation of sensitivity by cytokines. J Clin Invest 94:954-964.

Wolf DE, McKinnon CA, Daou M-C, Stephens RM, Kaplan DR, Ross $\mathrm{AH}$ (1995) Interaction with trkA immobilizes gp 75 in the high affinity nerve growth factor receptor complex. J Biol Chem 270:2133-2138.

Wyllie AH (1992) Apoptosis and the regulation of cell numbers in normal and neoplastic tissues: an overview. Cancer Metastasis Rev 11:95-103.

Yamashiro DJ, Nakagawara A, Ikegaki N, Liu XG, Brodeur GM (1996) Expression of $\mathrm{TrkC}$ in favorable human neuroblastomas. Oncogene 12:37-41. 